\title{
Penataan Hukum Pemerintahan, Upaya Percepatan Program Pembangunan Tingkat Kabupaten ${ }^{1}$
}

\author{
Oleh: DR. Patawari, S.HI.MH. ${ }^{2}$
}

\section{Pendahuluan}

Indonesia merupakan Negara hukum, sebagaimana termaktub di dalam Pasal 1 UUD NRI 1945, maka seyogyanya pengelolaan pemerintahan, swasta, dan masyarakat berdasar pada hukum. Pengelolaan Negara berdasarkan hukum, yang berdasarkan pada kontitusi tersebut tujuannya adalah keadilan dak kemakmuran. Instrument di dalam mencapai tujuan Negara tersebut adalah, yakni; mencerdaskan kehidupan bangsa, melindungi segenap bangsa Indonesia, dan ikut melaksanakan ketertiban dunia dengan berlandaskan pada nilai-nilai ketuhanan, kemanusiaan keadilan, persatuan, kerakyatan (demokrasi), dan keadilan sosial.

Pengelolaan Negara oleh pemerintahan dalam mencapau tujuan Negara, diperlukan adanya hubungan kerjasama yang baik dengan beberapa organ pemerintahan pertama secara vertikal dengan adanya hubungan antara Pusat dan daerah. Kedua, Horizontal yakni hubungan pemerintahan eksekuti, legislative, dan eksekutif, ketiga, diagonal hubungan antara beberapa komisi dan atau lembaga yang sah oleh Negara berdasarkan tugas pokok dan fungsi masing masing. Sehingga koordinasi yang secara harmonis tersebut dapat membawa pemerintahan pusat maupun daerah dalam rangka mencapai cita negara yang adil dan makmur.

Hubungan kerjasama antara pemerintahan dalam negara tersebut diperlukan adanya sistem hukum yang dapat memberikan ruang kebebasan pemerintah, swasta dan masyarakat di dalam menjalankan hak dan kewajiban serta tugas dan fungsi masingmasing. Sebab tanpa sistem hukum sebagai tool (alat) maka tentunya pemerintah sulit untuk bergerak bebas dalam menjalankan

\footnotetext{
${ }^{1}$ Dipresentasekan pada Dialog diskusi "tematis dan dialog publik" Pemerintah Kabupaten Pinrang. Di rumah Jabatan Bupati Pinrang, 13 Desember 2015

2 Dosen Hukum Tata Negara, Wakil Dekan Fakultas Hukum UIT, Alumni Program Doktor IImu Hukum UNHAS, Direktur indoWACANA (lembaga pengkajian, penelitian, sosialisasi dan Perancangan peraturan perundang undangan dan kebijakan pemerintahan). Pengalaman Konsultan Ahli Hukum Ranperda Pada Kab : Mamuju, Gowa, Sidrap, Pare-pare, Sinjai. Pinrang dan Prov.Sulsel Cp. 081355081182
} 
pemerintahan, karena konstitusi telah menentukan bahwa negara indonesia adalah negara hukum.

Dengan kata lain, akan sulit untuk bekerja tanpa ada aturan, apatahlagi dengan banyaknya lembaga -lembaga yang dapat saja menganggap tindakan pemerintahan tersebut merupakan tindakan yang melawan hukum. Sedangkan diketahui bahwa tindakah suatu pemerintahan dapat saja berakibat pada pidana, perdata, dan hukum administrasi negara. Maka dengan demikian, secara psikologi pemerintah tentu akan menjadi "ketakutan" tidak menjalankan tugasnya secara baik, akibatnya pelayanan masyarakat akan tidak terwujud.

Selain dari pada sistem hukum, diperlukan adanya profesionalitas pemerintah sebagai penyelenggara tugas negara untuk dapat menafsirkan tugas dan fungsi masing-masing. Sebagaimana pandangan Laorance Friadman bahwa hukum akan bisa tegak jika 3 (tiga) sistem Hukum berjalan seiring. Pertama Substansi Hukum, struktur hukum, dan kultur hukum. Sebagai penyempurnaan dari itu Sadjipto menambahkan diperlukan adanya fasilitas. Sedangkan Achmad Ali diperlukan adanya profesionalitas. Maka dengan demikian sistem hukum dapat berjalan baik, selain diperlukan substansi, struktur, dan kultur hukum. Juga, diperlukan fasilitas dan profesionalitas penyelenggara pemerintahan.

Pengelolaan negara tidak ansich kehendak dan keinginan masyarakat atau pemerintah tanpa dasar, kesemuanya harus berdasarkan pada ketentuan ketentuan hukum yang telah disahkan oleh pemerintahan baik ditingkat pusat maupun daerah.

Olehnya itu, pembangunan daerah Kabupaten Pinrang dalam jangka waktu pendek paling tidak adalah berdsarkan pada RPJMD, hal tersebut menjadi tolak ukur pelaksanaan pembangunan. Dengan demikian barometer keberhasilan dalam suatu daerah adalah berdasarkan pada rencana tersebut dalam rangka mewujudkan daerah yang adil dan makmur.

\section{Pembahasan}

Pertumbuhan ekonomi Kabupaten Pinrang 5 tahun terakhir (2009-2013) ${ }^{3}$, tumbuh rata-rata sebesar 7,2\% per tahun dengan penyumbang kontribusi terbesar dari sektor agrokompleks sebesar 57\% per tahun. Namun, pertumbuhan PDRB dari kapasitas produksi sektor perdagangan, hotel dan restoran hanya rata-rata sebesar $13,4 \%$

${ }^{3}$ Data BPS Pinrang 2015 
per tahun. Demikian pula di sektor industri non migas, pertumbuhan PDRB mencapai rata-rata 5,3\% per tahun sedangkan pertumbuhan PDRB dari sektor konstruksi rata-rata hanya $4 \%$ per tahun. Artinya bahwa Pinrang mengalami perkembangan dari tahun ketahun, hal tersebut menjadi modal besar untuk dikembangkan sesuai dengan kondisi lokal. Pertimbangan lain adalah penataan pemerintahan yang baik dengan berdasar pada ketersediaan hukum yang memadai.

\section{Penataan Pemerintahan baik}

Pemerintahan yang bersih merupakan cita dasar dalam pengelolaan negara dalam memberikan pelayanan kepada masyarakat berdasarkan konstitusi dan peraturan perundang undangan yang berlaku.

Bahwa pemerintahan yang bersih, sebuah istilah yang telah menjadi asas dalam peraturan perundang undangan, khususnya pada peraturan yang berkaitan dengan pengelolaan pemerintahan. Disaat bersamaan, memang negara Indonesia masuk dalam kategori negara yang dianggap tidak bersih, baik karena korupsi, kolusi dan nepotisme yang menggerogoti bangsa Indonesia hingga kini. sebagai antisipasi dari hal tersebut maka, dengan hadirnya beberapa komisi atau lembaga yang disahkan oleh negara untuk bekerja secara khsusus sesuai dengan tugas fungsi masing-masing. Seperti contoh, KPK, Komisi Ombudsman, Komisi anak Perempuan, KPU, dan beberapa lembaga lainnya. hadirnya beberapa lembaga tersebut paling tidak menjustifikasi bahwa pemerintahan tidak mampu untuk bekerja secara optimal.

Sistem pemerintahan yang baik bukan hanya dimaksudkan pada pemerintah akan tetapi juga dimaksudkan swasta dan masyarakat. Bahwasanya pemerintahan tidak dapat bekerja baik tanpa didukung oleh pihak swasa, demikian dengan masyarakat secara umum. Olehnya itu, nalar pembangunan yang baik adalah adanya keterlibatan antara pemerintah, swasta, dan masyarakat dan diatur dalam ketentun hukum.

Bahwasanya baik pemerintah, swasta ataupun masyarakatakan sulit untuk melaksanakan suatu tugas dan fungsinya tanpa aturan. Sebab secara filosofi dengan hadirnya hukum akan memberikan kemerdekaan dan kebebasan pemerintah di dalam menjalankan tugasnya dengan baik. Sebaliknya, pihak yang tidak bermaksud baik (jahat) di dalam melaksanakan hak dan kewajiban atau tugas dan fungsinya, maka dengan adanya aturan akan membatasi dirinya untuk melakukan tindakan (kesewenag-wenangan). 
Sebagai instrument di dalam melaksnakan pengelolaan negara melalui keterlibatan pemerintahan, swasta dan masyarakat. Adalah berdasarkan pada beberapa produk perundang undangan yang terhirarhis mulai dari undang undang, Perda, hingga pada perdes.

\section{Hukum yang memadai}

Konsep otonomi daerah melalui pemerintahan daerah tingkat Kabupaten, diberikan kewenangan didalam merancang peraturan perundang undangan ditingkat daerah yakni perda. Olehnya itu dalam rangka melaksanakan pemerintahan yang baik maka instrument hukum harus memadai ditingkat daerah sesuai dengan kebutuhan daerah masing-masing, serta tidak bertentangan dengan peraturan perundang undangan baik secara vertikal, horizontal, maupun benturan perundang undangan secara diagonal.

Penataan hukum seharusnya dilakukan ditingkat daerah, olehnya itu pemerintahan khususnya pada Dewan Perwakilan Rakyat Daerah (DPRD) ditingkat Kabupaten, mengutamakan adanya regulasi untuk dapat menjadi dasar pelaksanaan pemerintahan dan pelayanan masyarakat. Sekalipun tidak dipungkiri bahwasanya dinamika pada lembaga legislative baik ditingkat pusat maupun daerah adalah kecenderungan pada tindakan politik yang serba politis, namun hal tersebut dalam lembaga legislatif adalah tindakan lumrah. Namun demikian, karena jabatan legislatif adalah jabatan trus (kepercayaan) yaitu jabatan oleh karena adanya kepercayaan oleh masyarkaat, untuk sebaliknya dapat memperhatikan kebutuhan masyarakat.

Penataan hukum, dengan menghadirkan regulasi yang sesuai dengan kehendak dan keinginan masyarakat dan pemerintah ditingkat daerah, bukan hanya untuk pengaturan sistem pemerintahan dan masyarakat ditingkat daerah. Namun, membuka ruang pihak pemerintahan baik provinsi maupun pusat, serta pihak swasta dalam rangka memasukkan investasi. Dengan dalil bahwa daerah tersebut telah memiliki payung hukum. Sebagaimana diketahui bahwa pihak luar daerah akan mudah berinvestasi, oleh karena adanya kepastiaan hukum yang yang memadai di daerah. Sebaliknya tanpa adanya payung hukum maka dengan demikian investor enggan untuk masuk oleh karena adanya kelabilan, dan ketidak pastian akan rasa aman, nyaman yang berimplikasi pada tidak adanya keuntungan yang diperoleh.

Olenya itu anggota DPRD dan Bupati sebagai mitra regulator, harusnya menyediakan seperangkat Peraturan daerah yang dapat menciptakan sistem pemerintahan yang baik dalam pada tingkat Kabupaten. Baik peraturan daerah yang dinisiatifkan oleh DPRD melalui Badan Legislasi, maupun juga rancangan peraturan daerah 
yang diinisiatifkan oleh Pemerintah Daerah melalui Kepala Bagian hukum. Demikian juga dengan Lembaga Non Govermant Organisation juga dapat saja membantu pemerintahan dengan mengaspirasikan lahirnya peraturan daerah baik melalui pintu inisiatif Pemerintah daerah maupun DPRD.

Yang pada simpulannya bahwa, mengukur pemerintahan yang baik adalah menggunakan ukuran hukum. Bahwasanya dapat saja dalam suatu daerah melahirkan suatu kebijakan yang baik dan bermanfaat untuk kepentingan masyarakat namun karena tidak adanya ketersediaan payung hukum maka tentu tidak dapat dilaksanakan secara kontinuitas, dan tidak sedikit kebijakan suatu pemerintahan yang baik namun hal tersebut dianggap bertentangan oleh dengan hukum. Artinya bahwa semua kalangan dipastikan menginginkan adanya pelayanan, dan pengelolaan pemerintahan yang baik namun demikian tidak berarti harus bertentangan dengan hukum.

\section{Percepatan Program Pembangunan}

Nalar pembangunan dalam suatu daerah paling tidak barometer utama adalah mengacu pada RPJMD, sebagaimana Kabupaten Pinrang Tahun 2014-2019 telah ditetapkan dengan Peraturan Daerah Nomor 2 tahun 2014, sebagai acuan dalam penyusunan RKPD Kabupaten Pinrang Tahun 2015. Yang selanjutnya SPJMD tersebut dijabarkan dalam Rencana Kerja Pembangunan Daerah (RKPD)

Dalam rangka mengimlemantasikan perencanaan tersebut adalah dengan adanya upaya penguatan kualitas Sumber daya manusia, melanjutkan pengembangan dan pembangunan infrastruktur wilayah, revitalisasi infrastruktur yang ada, pengembangan tata ruang wilayah dan manajemen pertanian, lingkungan hidup, pengembangan perekonomian berbasis masyarakat, pemanfaatan teknologi tepat guna, penyelenggaraan tata kelola pemerintahan yang baik, kemitraan, penyediaan lapangan kerja, dan lain - lain. ${ }^{4}$

Olehnya itu, dengan adanya poundasi pembangunan tersebut maka harusnya didukung oleh perangkat hukum yang memadai, sebab pelaksanaan perencanaan tersebut banyak melibatkan kelembagaan di daerah, sehingga untuk tidak terjadi tumpang tindih tugas fungsinya, diperlukan penyatuan persepsi dan persepsi tersebut diikat dengan peraturan sesuai dengan ketentuan hukum yang berlaku.

\footnotetext{
${ }^{4}$ http://bappeda.pinrangkab.go.id/berkas_3_RKPD\%20TAHUN\%202015.pdf
} 
Terlepas dari perencanaan menengah Kabupaten Pinrang, maka pemberdayan potensi lokal daerah harus menjadi utama dalam suatu pembangunan. Hal tersebut guna menghindari perilaku masyarakat yang konsumtif, namun demikian mendorong masyarakat untuk bertindak secara produktif. Sebagai contoh pada salah daerah tingkat di Hongkong bahwasanya pada kawasan kecamatan tersebut sumber daya alamnya adalah kelapa, jika pihak investor hendak menginvestasikan modalnya katakanlah membangun hotel maka diberikan ruang kebebasan, namun ketentuan Hukumnya adalah pengelola hotel tersebut wajib menyediakan air Kelapa terhadap tamunya, sedangkan sandal hotel yang disediakan adalah harus ada unsur tempurung kelapanya.

Gambaran pengelolaan daerah yang berkearifan lokal tersebut tidak anti dengan modernitas dan kemajuan teknologi, namun menjadi wajib untuk potensi lokal diikut sertakan, akibatnya masyarakat daerah sekitar hotel tersebut akan berkembang seiring dengan kemajuan Hotel yang menyediakan khas daerah.

Sedangkan Kabupaten Pinrang merupakan daerah yang secara geografi menjadi lintas Provinsi, dan Kabupaten, Sumber daya alam yang melimpah, baik pertanian, perkebunan, perikanan (laut) Kabupaten Pinrang telah miliki. Diskursus kemudian adalah apakah perangkat hukum, kesatuan visi misi, pemerintahan telah sampai pada upaya percepatan pembagunan dengan berbasis pada kearifan lokal?

Berdasarkan hal tersebut sebagai contoh pertama, Kabupaten Pinrang salah satu makanan khasnya adalah Nasu Pelekko (NSP), namun demikian tengoklah di beberapa restoran ataupun Hotel apakah sudah menyediakan manan khas tersebut, atau mungkin saja hotel tersebut menyediakan makanan minuman yang bahan bakunya dari Polman, Sidrap, Pare, atau mungkin saja bahan baku minuman makannanya dari luar negeri. Maka tentunya yang di sejahterakan bukan masyarakat tempat berdirinya hotel tersebut.

Bahwa jika Kabupaten Pinrang terkenal dengan Berasnya "barra na barra" maka loncatan berpikir yang produktif atas sumber daya yang dimiliki tersebut, beras dihasilkan bukan hanya menjadi tepung tapi akan dijadikan roti. Akan tetapi, mungkin fakta lain bahwa roti yang di konsumsi di pinrang salah satunya dari Kabupaten Maros sedangkan Beras yang dibikin roti di Maros adalah beras yang berasal dari Pinrang. Logika pembangunan tersebut menjadi bagian penting, dalam penataan kabupaten dalam mewujudkan Kabupaten Pirang yang adil dan sejahtera \#\# 


\section{Kesimpulan}

Dalam rangka melakukan percepatan pembangunan dalam suatu daerah, maka diperlukan adanya kesepahaman persepsi pemerintahan baik legisaltif, ekeskutif dan yudikatif dengan mencacu pada visi misi Kabupaten.

Di dalam menyelenggarakan perencanaan pembangunan diperlukan adanya katersediaan sistem hukum dalam bentuk peraturan perundang undangan ditingkat daerah. Kiranya pemerintah di dalam melaksanakan pengelolaan daerah dan pelayanan pada masyarkaat memiliki kepastian hukum sesuai dengan tugas pokok dan fungsi masing-masing. Bahwa dengan adanya ketersediaan regulasi yang memadai ditingkat daerah. Maka pihak investor memiliki tingkat kepercayaan yang tinggi oleh karena adanya kepastian hukum padadaerah tersebut.

Pembangunan daerah Pinrang seharusnya mencerminkan kearifan dan potensi lokal, dengan bersinergi terhadap pembangunan modern sehingga daerah maju bersama -sama dengan masyarakat stempat. 